\title{
Reading Hebrews through Akan ethnicity and social identity
}

\begin{tabular}{|c|c|}
\hline $\begin{array}{l}\text { Authors: } \\
\text { Seth Kissi } \\
\text { Ernest van Eck }\end{array}$ & ${ }^{2}$ (1) \\
\hline $\begin{array}{l}\text { Affiliations: } \\
{ }^{1} \text { Biblical Greek } \\
\text { Testament Stu } \\
\text { Theological Se }\end{array}$ & $\begin{array}{l}\text { and New } \\
\text { dies, Trinity } \\
\text { minary, Ghana }\end{array}$ \\
\hline \multicolumn{2}{|c|}{$\begin{array}{l}\text { 2Department of New } \\
\text { Testament Studies, Faculty of } \\
\text { Theology, University of } \\
\text { Pretoria, South Africa }\end{array}$} \\
\hline $\begin{array}{l}\text { Research Proj } \\
\text { Registration: } \\
\text { Project Leader } \\
\text { Project Numb }\end{array}$ & $\begin{array}{l}\text { ect } \\
\text { r: E. van Eck } \\
\text { er: } 2400030\end{array}$ \\
\hline \multicolumn{2}{|c|}{$\begin{array}{l}\text { Dr Kissi participated in the } \\
\text { research project 'Socio- } \\
\text { cultural Readings', directed } \\
\text { by Prof. Dr Ernest van Eck, } \\
\text { Department of New } \\
\text { Testament Studies, Faculty of } \\
\text { Theology, University of } \\
\text { Pretoria, South Africa. }\end{array}$} \\
\hline \multicolumn{2}{|c|}{$\begin{array}{l}\text { Corresponding author: } \\
\text { Ernest van Eck, } \\
\text { ernest.vaneck@up.ac.za }\end{array}$} \\
\hline $\begin{array}{l}\text { Dates: } \\
\text { Received: } 10 \mathrm{D} \\
\text { Accepted: } 02 \mathrm{~F} \\
\text { Published: } 21\end{array}$ & $\begin{array}{l}\text { ec. } 2016 \\
\text { eb. } 2017 \\
\text { Apr. } 2017\end{array}$ \\
\hline \multicolumn{2}{|c|}{$\begin{array}{l}\text { How to cite this article: } \\
\text { Kissi, S. \& Van Eck, E., 2017, } \\
\text { 'Reading Hebrews through } \\
\text { Akan ethnicity and social } \\
\text { identity', HTS Teologiese } \\
\text { Studies/Theological Studies } \\
\text { 73(3), a4490. https://doi. } \\
\text { org/10.4102/hts.v73i3.4490 }\end{array}$} \\
\hline \multicolumn{2}{|c|}{$\begin{array}{l}\text { Copyright: } \\
\text { (c) 2017. The Authors. } \\
\text { Licensee: AOSIS. This wo } \\
\text { is licensed under the } \\
\text { Creative Commons } \\
\text { Attribution License. }\end{array}$} \\
\hline \multicolumn{2}{|l|}{ Read online: } \\
\hline 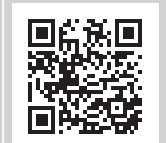 & $\begin{array}{l}\text { Scan this QR } \\
\text { code with your } \\
\text { smart phone or } \\
\text { mobile device } \\
\text { to read online. }\end{array}$ \\
\hline
\end{tabular}

The Akan people of Ghana have concepts of ethnicity and social identity which are similar to those found in the Mediterranean world, which find expression in the issues addressed in the letter to the Hebrews. This similarity makes the reading of Hebrews in light of Akan ethnicity and social identity possible, giving one the expected meaning from the perspective of those concepts as within the original context of the audience. This article therefore discusses some theories on ethnicity and social identity as well as the Akan people of Ghana and their concepts of ethnicity and social identity. It further explains the social context of the letter of Hebrews against which Hebrews is then read in light of Akan ethnicity and social identity. The focus of this reading is on how the ethnic identity of the readers presented in Hebrews enhances the social identity of the readers and provides the means by which the author's appeal to his readers for their faithfulness to God becomes meaningful and urgent.

\section{Introduction}

This attempt to read Hebrews from an Akan perspective on ethnicity and social identity is informed by the fact that there is similarity between the concepts of ethnicity and social identity of the first-century Mediterranean society (which find expression in, inter alia, Hebrews), and the concept of ethnicity and social identity in the Akan society of Ghana. ${ }^{1}$ It is therefore possible to read Hebrews' appeal to his readers entirely in terms of ethnicity and social identity through the lenses of Akan ethnicity and social identity. This reading should be done by taking into consideration the peculiar Jewish and Christian elements introduced into the author of Hebrews' presentation. In addition, one should bear in mind the context in which the believers had to be admonished to endure suffering in faithfulness to God and the Christian group.

\section{Ethnicity}

The term 'ethnicity', derived from the Greek $\tilde{\varepsilon} \theta v o \varsigma$ (ethnos), was coined by the sociologist W.L. Warner in 1942 and has been used in various ways to refer to specific groups of people (Van Eck 2014:52, n. 4). Some regard ethnicity in fixed terms as describing people who share common features that are naturally given, as in Primordialism (see Duling 2010:71; Siapkas 2014:67). Others think of the features of ethnicity as the ways by which groups of people socially define themselves as distinct from other groups. Such people find fluidity in the features of ethnicity, as in the case of Constructionism (see Duling 2010:72; Sparks 1998:18). ${ }^{2}$ Ethnic features are usually given as kinship, myth of common ancestry, homeland, customs, shared historical memory, religion, phenotypical features and name (Duling 2010:71-72). Almost all the features that appear as natural and fixed, such as homeland and ancestry, still find fictive use that enables groups to take on some particular ethnic identity. Even one's participation in the religious practices and customs of a particular religion makes one an integral part of that community (see Buell 2005:43-44; Cromhout 2014:538-539, following Bell 1997:193). The creation of ethnic identity with the help of the construction of myths of common origin has been found among many groups who were not naturally part of the ethnic group now constructed. Christians were not alone in drawing on some explanations, adaptations and reinterpretations of human history in a bid to explain their emergence on the historical scene, the assertion of their superiority and the universalising ideas

1.This article represents a reworked version of aspects from the PhD dissertation of Seth Kissi, titled Social identity in Hebrews and the Akan community of Ghana, in the Department of New Testament Studies, University of Pretoria, with Prof. Dr Ernest van Eck as supervisor.

2.Barth (1969:11) is of the view that much can be gained by regarding this very important feature of ethnicity as implication or result, rather than a primary and definitional characteristic of ethnic group organisation. Van Eck explains that most studies on ethnicity show that the term can be understood in terms of the attributes of a specific culture and how that culture differs from other cultures (Van Eck 2014:52).

Note: This article represents a reworked version of aspects from the PhD dissertation of Seth Kissi, titled 'Social identity in Hebrews and the Akan community of Ghana', in the Department of New Testament Studies, University of Pretoria, with Prof. Dr Ernest van Eck as supervisor. 
of their group. ${ }^{3}$ Because of its emphasis on differences between groups, ethnicity is a basic way of expressing one's social identity.

\section{Social identity}

Social identity is defined as 'that part of the individuals' selfconcept which derives from their knowledge of their membership of a social group (or groups) together with the value and emotional significance attached to that membership' (Tajfel 1982:2; emphasis in the original). ${ }^{4}$ Social identity focuses on the self-concept and evaluation that one derives from one's membership in any group(s), either by oneself or as perceived by others. ${ }^{5}$ To achieve positive social identity, which implies positive group identity, a process of comparison and evaluation is maintained in which the ingroup favourably differentiates itself from outgroups (Kuecker 2014:71). As Esler observes (in following Tajfel 1978:28), our sense of belonging to a group actually has three dimensions, namely (1) 'the cognitive', which is the simple recognition of belonging to a group; (2) 'the evaluative', which covers the positive or negative connotations of belonging; and (3) 'the emotional', which refers to attitudes members hold towards insiders and outsiders (Esler 1998:42).

\section{The Akan people of Ghana}

Almost all the important aspects of the history and culture of the Akan people of Ghana have been recorded by writers such as Rattray (1929), Busia (1954), Meyerowitz (1958), Danquah (1968), Fortes (1975), Opoku (1977), Appiah (1992), Gyekye (1996), Buah (1998), Sarpong (2002), NkansahKyeremanteng (2010) and Awinongya (2013). While a repetition of their work is unnecessary, this study requires a concise introduction of the Akan people and their concepts of ethnicity and social identity. These concepts are scattered in many works on the Akan people and has not yet been put together in writing as the social identity of the Akan people.

Akan is the largest ethnic group in Ghana, making up 47.3\% of the population of Ghana (Ghana Statistical Service 2013:61). They comprise the Bono, Asante, Adanse, Twifo, Asen, Fante, Akuapem, Akyem, Akwamu, Kwahu, Sehwi, Awowin, Nzima and Ahanta (Buah 1998:8). The name Akan, according to Danquah (1968:198), means 'foremost, genuine' (from kan, first,) and is the corrupted form of Akane or Akana,

\section{Buell $(2005: 90-91)$ helps us to understand that Christians used biblical and Greek explanations, adaptations and reinterpretations of human history in this respect. He tells us how human history received adaptations and reinterpretations from Judeans, Greeks, Egyptians and Romans among others with the view to emphasising their original unity with all people as well as their uniqueness.}

4. Henri Tajfel is identified as the founder of social identity theory (Esler 2014:13) Though the seminal experimental results that led to social identity theory were reported by Tajel and others in an article published in the inaugural volume of the European Journal of Social Psychology in 1971, it was not until 1978 that a work with his colleagues at Bristol University edited by Tajfel on social identity was published (Esler 2014:13; Jokiranta 2013:77). This initial work was elaborated in the 1970s and 1980 s, especially by Tajfel's student and follower, John C. Turner, who is credited with self-categorisation theory (Jokiranta 2013.78). Social categorisation results in with seff-categorisation the (Jorion generalisations can be made, for example, 'All Americans are loud' and 'Cretans are always liars' (see, e.g. Tt 1:12; Kuecker 2014:70).

5.As has been observed by Turner, social identity refers to self-descriptions related to formal and informal group memberships such as sex, nationality, occupation and religion (Turner 1984:526) corrupted by the early Arabs of the Sudan in Ghana and the early Europeans who visited the coast of West Africa in Guinea. The best known representatives of the Akan race are the Ashanti, Fanti, Akim, Akuapim, Assin and several of the present Twi-speaking races of the Gold Coast (Danquah 1968:198). ${ }^{6}$ Akans have a rich variety of dialects which are related and shared in various degrees of vocabulary and other linguistic elements. These dialects which are mutually intelligible include Asante, Akuapen, Akwamu, Fante, Akyem, Agona, Assin, Denkyira, Twifo, Wassaw, Kwahu, Bron and Buem (Agyekum 2006:206). ${ }^{7}$ The use by some scholars of the name Akan, to refer to the languages spoken by various groups, coincides more or less with the ethnographic use of the name Akan (Dolphyne n.d.:1, 2). ${ }^{8}$ Akan is spoken as a native language in 6 of the 10 regions in Ghana, namely in the Ashanti, Eastern, Western, Central and the Brong Ahafo Regions (Agyekum 2006:206). ${ }^{9}$

There is hardly any consensus on the origin of the Akan people. Some of the suggestions hold that the Akans may have come from some parts the Sudan, the old Mali Empire, Burkina Faso and even from Mesopotamia where they had close connection with Israel. The inclination of majority of scholars is towards the southern part of the Saharan region, whether identified with the old Ghana or Mali Empires. ${ }^{10}$ There is, however, greater agreement that it was in the southern part of West African forest region that the ethnogenesis of the various Akan groups took place. ${ }^{11}$

\section{Akan ethnicity}

Shumway (2011:19) observes that ethnic identity in Ghana, as elsewhere in Africa, is neither an unchanging relic of the

$6 . S a l m$ and Falola (2002:6) divide the Akan into two groups, the Fante and the Twi, without identifying any basis for the division, noting that the Fanti came first, settling predominantly in the area around what is now Cape coast, probably in the thirteenth century to be followed later by the Twi some of whom inhabited much f the central region, the forest country to the south, between the Volta and Tano of the central region, the forest country to the south, between the Volta and Tano Rivers. Some of them also migrated east and created the Baule community in what is now Côte dlvoire. The Bono was the first Akan kingdom to be established in the then Gold Coast in the thirteenth century, long before the Portuguese first arrived
in 1471 (Nkansa-Kyeremanteng 2010:36; Salm \& Falola 2002:6).

7.Kofi Agyekum is a professor of Linguistics of the University of Ghana.

8.Dolphyne is an Akan who hails from Achinakrom in Asante and has profound knowledge of the Akan people and their culture. She is a professor in linguistics who worked and retired as Head of the Department of Linguistics of the University of Ghana.

9.Though he mentions six, he ends up listing five. It is only when Brong Ahafo is understood as two groups made up of Brong and Ahafo, as is traditionally done, that one can reckon six regions, but as the case is, Brong and Ahafo do not constitute two political regions in Ghana. Politically, therefore, one can speak of five regions where the Akan language is spoken.

10.Danquah (1968) and Meyerowitz (1958) favour the southern part of the Saharan hypothesis. So are Davidson, Buah and Ajayi (1965:87), who presume western hypothesis. So are Davidson, Buah and Ajayi (1965:87), who presume western
Sudan. Buah's (1998:9) guess is the southwest region of the present day Republic Sudan. Buah's (1998:9) guess is the southwest region of the present day Republic
of Burkina Faso. Tieku (2016:118), for his part, notes oral traditions that identify the origins of the Akan people with places like old Mali Empire and even to Mesopotamia.

11.As Akans kept moving southward, they settled below the Black Volta River, where Asaman, their leader, founded the Bono Kingdom, which became the first great Akan State in Ghana (Meyerowitz 1958:20) and the cradle of the Akan people with nearly all the different groups of the Akan tracing their original homes to Bonoland (Buah 1998:9). Meyerowitz (1958:17) describes the Akan as people with a mixed ancestry. He notes that Akans incorporated many of the inhabitants into their clans ancestry. He notes that Akans incor clan as they settled along the Niger bend as was the custom among matrilineally organised peoples. Though the people were originally of much the same stock as (Meyerowitz 1958:18-19). While Tieku (2016:199) and Davidson et al. (1965:87) speak of factors that accounted for their movement from the south of the Saharan speak of factors that accounted for their movement from the south of the Saharan
region to their present locations, Fortes $(1975: 253)$ gives an example of the process of evolution of mixed race among the Asantes. 
distant African past nor a recent colonial invention applied arbitrarily to a population. Ethnic identities such as Akan, Fante and Asebu are manifestations of shared experiences among communities that evolved over time. With this changing nature of ethnic identity in mind, the interest of this article is centred on the views that are known to be operational in many Akan thoughts in terms of who Akans are. In some cases, such views could be traditional and not necessarily what all Akans now hold.

Adu Boahen, a professor of history (1966, in Dolphyne n.p:3), lists the use of common calendar, common religious beliefs, naming ceremonies, marriage, matrilineal systems of inheritance and monarchical system of government as cultural traits and institutions identical with all Akans in addition to language. The seven matrilineal 'clans', called abusua, and seven patrilineal groupings called nton or kra, are common features of the Akan people. ${ }^{12}$ Buah (1998:8) identifies inheritance through the maternal line as one peculiar practice of the Akan people (Buah 1998:8). This is true whether in terms of property or stools ${ }^{13}$ (Tieku 2016:87). It has however been noted that though the Akuapems are Akans, they inherit from the patrilineal side (Eshun 2011:910). ${ }^{14}$ Chieftaincy used to be a unique mark of the Akan communities according to Dolphyne. She intimates that on the coast the Gas and Ewes were ruled by their local priests, and that chieftaincy among them was introduced for the convenience of governance by the British (Dolphyne, pers. comm., 04 July 2016).

Nkansa-Kyeremanteng (2010:26), one of the most cited historians on Akan people, gives some indications of the meaning of the name Akan. His discussion of the subject first points to the meaning of the Twi word kan, which means 'first', and the suggestion that the Akans were the first settlers of Ghana. Associated with this view is the notion of superiority, which is reflected in a complex way in the Akan saying '[a] nimguase mfata Okani ba' [The Akan does not deserve disgrace]. Related to this notion is the view that the Akans were the most polite people among those with whom they lived. According to Danquah, ' $[t]$ he word Akan, ordinarily means a nice, refined, well-mannered man: civilised or cultured person' (see Nkansa-Kyeremanteng 2010:26). In respect of what is characteristic of the Akan in general, NkansaKyeremanteng (2010:27) mentions comeliness, bravery and

12.While Buah has seven without listing them, Nkansa-Kyeremanteng (2010:33-35) lists 12 Akan nton.

13.The stool is the symbol of authority of Akan chiefs and kings, and it is that on which they sit in the palace and at durbars. The office of the chief is usually referred to as the stool. The inheritance and succession to Akan chiefs and kings follow the matrilineal succession and inheritance of property within the Akan families.

14.This is, however, not true with all Akuapem people. The people of Akropong have matrilineal inheritance. Those who have patrilineal inheritance, like the people of Adukrom, do not consider themselves Akans. Some of them who were spoken to indicated that they are Guans (Pamela Dickey Young, School of Religion, Queen's University, pers. comm., 22 July 2016). Dolphyne (n.d.:2) notes that the Guans do not belong to the Akan ethnic groups, though some scholars include them in the language family of the Akan, Volta-Comoé or Volta-Bendama. Another interesting language family of the Akan, Volta-Comoe or Volta-Bendama. Another interesting exception is the fact that the people of Anum, though Guans, have matrilinea inheritance, the only exception among the Guans as related by Martin Oben (Department of Old Testament, Trinity Theological Seminary, Ghana, pers. comm. 06 August 2016), a Guan from Anum. An exception to the rule of Akan matrilinea inheritance is the case in which at the creation of a stool it was stated that it is fo the children of the first occupant. In this case, the inheritance of the stool becomes patrilineal (see Tieku 2016:87) their regard of sycophancy as disgraceful, ignoble and immoral, as well as their love for freedom. These are the reasons why Akans esteem and honour their sons and daughters who exhibit bravery. ${ }^{15}$

In so far, as ethnic identity is very important for the Akan, several attempts are made to project and strengthen the desired identities of the various groups within the Akan society. One of the ways in which Akans seek to realise their ethnic identity is through the use of totems. Eshun (2011:34; in following Quarcoopome 1978) intimates that animals are chosen as totems based on the qualities of the animal a particular clan wants to emulate. To the extent that character traits are considered to be passed on to children by their parents, some particular character traits are associated with particular clans or families. Though the mother's line determines the clan (Abusua) to which a person belongs, every individual also belongs to a nton of his father, believed to be the spirit of the father that protects the person. It is believed that the bond established by the nton between the child and the father determines the characteristics that the child takes, such as intelligence, wisdom, knowledge and general character (Nkansa-Kyeremanteng 2010:33). People who belong to the same nton share some common features. There are 12 nton, and each has its own totem, taboos, peculiar characteristics and responses to their greetings. The insistence by some Akans on being given the right response of their clans or $n$ ton to their greetings is indicative of how important ethnic identity is for Akans.

\section{Social identity in Akan society}

Akans are very conscious, deliberate and explicit on their social identity. This finds expressions in proverbs that speak to the need for positive evaluation of one's group, as well as the practice of negative evaluation of one's opponent or outgroup. The Akan adage [o]bi mfa ne nsa benkum nkyere n'agya akura [no one points to his or her father's village with his or her left hand] speaks to the consciousness of the Akan that one must speak well of one's group. The fact that the use of the left hand in public is a sign of impoliteness and disrespectfulness gives significance to the adage in terms of Akan concepts of social identity. Similarly, [s]e woresua wo tamfo asa a, wokyia wo pa [you twist your waist when imitating your enemy in dancing (to give the impression that your enemy is deformed)] speaks to an Akan view on social identity in which one presents others (of outgroups) unfavourably.

How important social identity is in the Akan society can be appreciated from the way in which Akans speak fondly of their group when it is their source of pride. Group members make efforts to avoid anything that does not enhance the honour and pride they derive from their groups. Akans, in general, have a sense of pride as represented in the adage

15.Nkansa-Kyeremanteng $(2010027)$ believes that it is in their love for freedom that their regard of sycophancy as disgraceful, ignoble and immoral is exhibited. He describes the Akans as people who exhibit vast homogeneity linguistically and culturally, factors which have served to assimilate their immediate neighbours culturally, factors which have served to assimilate their immediate neighbours
because of the superior political authority they exercised over others (NkansaKyeremanteng 2010:26) 
Animguase de efanyinam owu [disgrace is worse than death]. ${ }^{16}$ It should also be noted that the self-understanding of the Akan is one of a civilised person, a foremost person, as the word kan (first) implies (Danquah 1968:198). It is from this sense of pride that others who do not speak the Akan language are described as Apotofo [babblers]. ${ }^{17}$

The fact that members of Akan clans and nton share common character traits gives significance to the belief that the members of the clan and nton are descendants of one ancestor, a belief which has a masculine variant in the first-century Mediterranean society. ${ }^{18}$ The use of these character traits, as appellations by members of the clans, shows the pride they take from their membership of these clans. It is not uncommon to hear members of the Asona Clan priding themselves in the beauty associated with their clan. ${ }^{19}$ If Akans greet and demand that specific responses of their clan are given to their greetings, it is not merely to identify with their clans or nton but also because of the pride of associating with the positive evaluation of the image of the respective clan or $n t o n .^{20}$

\section{Social context of Hebrews}

The 'few words of exhortation' (Heb 13:22), as the unknown writer describes in his letter to the unknown readers, are to be understood within the context of the social problem the author found urgent for his address. His mixed Jewish and non-Jewish Christian believing community (association) faced the tendency to fall back into the dominant and more powerful groups from which they had come to join the Christian group. Their membership with the Christian group meant that they stopped doing things that citizens of the city and, for that matter, the Roman Empire were doing as patriotic members of their community. Avoiding the sacrifices to the gods now meant that they did not want the gods to bless the Empire with peace and prosperity (see Buell 2005:60). Their refusal to participate in emperor veneration

16.Another adage - Animguase mfata Okanni ba [disgrace is not becoming of an Akan] - has already been noted.

17.It must be observed that all the ethnic groups in Ghana have some derogatory ways of referring to each other. According to R. Agbanato (pers. comm., 02 August 2016), an Ewe and security officer at the Trinity Theological Seminary, Ewes call the tribes in the north Dzogbeawo (Northerners). The term, according to him, is a negative term because it describes them in terms of where they come from. Ebluawo is the term Ewes use for the Akans who are usually called Asantes. The term means they are neither Fantes nor Gas. They also call Gas Egeawo, meaning foreigners. J. Adiok (pers. comm., 02 August 2016), a Bulisa from the North and also a security officer at Trinity Theological Seminary, explains that Ewes are referred to as Zoburig, his tribe in the North, a negative expression that means that they cannot be trusted. They also call Asantes (an expression they use for all Akans) they cannot be trusted. They also call Asantes (an expression they use for all Akans) Kabonga, a term which recalls their activities as violent captors of slaves in the
north during the times of slave trade.

18.Duling (2010:74) notes that, except for magical texts, genealogies usually followed single male line ('unilinear patrilineal descent'); the most common form of identity was ' $X$ son of $Y$ (son of Z)', as in 'James son of Zebedee' (Matt 4:21).

19.It is said of the members of the Asona Clan that they are beautiful to the exten that the rear of their head is as beautiful as someone else's face. The saying won atiko na ete se obi anim [the rear of their head is as beautiful as someone else's face] gives expression to this pride (see Tieku 2016:90).

20.Within the extended family and the nuclear family, members enjoy some positive or negative social identity depending on the social image of the family concerned. Families which have members working or studying overseas see that as a source of pride. The same can be said of families which have members occupying significant pride. The same can be said of families which have members occupying significant public or social positions in such fields as politics, public and civil services. People who have made good names in any respect become a source of pride for the a account of this ascribed honour. On the contrary, those families which have rampant records of murder, thefts and other vices become a reproach and thei members hardly want to identify with them. was regarded as a threat to the political unity and stability. Association with the Christian group therefore gave one a bad image in the Empire. Members of the larger society would therefore avoid associations with any member of the group to show their disapproval of their deviant behaviour (see DeSilva 2012:46). In most cases, trade associations and families would disown and reject their members who join the Christian group. They would do this to dissociate themselves with the 'antisocial' and 'unpatriotic' behaviour of the Christians and save the image of their families and associations (DeSilva 2012:49-50). Because of their disfavour with the society, the Christians could have been victims of mob action and social hostility without the protection of the city authorities who would usually look on unconcerned as in the case of the stoning of Stephen and the beating of Paul to near death (Ac 7:54-60; 14:19). ${ }^{21}$

The believers had previously stood firm in the face of social abuse and other mistreatment, while identifying boldly with other believers who were imprisoned or mistreated (Heb 10:32-34). Now, the pressure had been sustained on them for a long time that, coupled with other factors, they were beginning to show signs of giving up on their membership of the Christian group and losing confidence in the Christian message (Heb 2:1). Some had actually stopped attending the meetings of the Christian group (Heb 10:25). Leaving the Christian group meant that one no longer had Jesus as his or her saviour. ${ }^{22}$ If such movement out of the group continued, it would spell doom for the future of the church (DeSilva 2012:163). The writer's sense of urgency, reflected in his stern warnings in the letter, is indicative of the seriousness of the situation he addressed. The situation also meant that the believers had lost a positive social image and stood in a position of disadvantage when it comes to power. One of the ways in which the words of the author could be understood as addressing this social situation of his audience is to read his words through the lenses of ethnicity and social identity, because these issues lie at the core of the experience of the readers. In this case, the author intended his letter to address issues of ethnicity and social identity, and his words would reflect and find meaning in terms of those issues in the experience of his audience.

\section{Reading Hebrews in light of Akan ethnicity and social identity}

The author of Hebrews describes the members of the Christian group with specific ethnic terms that distinguished them from others who do not belong to the group. These ethnic descriptions are intended to call to mind the social institutions and their related expectations that oblige the

21.See for instance, Cockerill (2012:501, citing Eusebius, Hist. eccl. 3.17; Craddock 1998:125). This finds typical expression in the Akan saying, me na memmo wo, na mmom se obi rebo wo a, merenye wo [I will not beat you but I will not save you when someone is beating you].

22. Having group-oriented selves, and therefore very concerned to adopt the viewpoints of the groups (their in-groups) whose fate they shared (Malina 1996:45), the Mediterranean person would never have considered Jesus as a personal Lord and Saviour or as a personal Redeemer. To them, Jesus was the church's (the group's) Lord and Saviour, and it was by belonging to the church (the group) that one experienced the presence of the Lord (Malina 1996:45). 
readers to respond to God and the Christian group with the right attitude and behaviour. On the basis of these social expectations, the believers are required to participate in the attitudes that are characteristic of the group. At the same time, these social expectations drive home how evil it is for the believers to act contrary to what the author demands from them. These social scripts further justify the severity of the punishment that must be expected in the event of breaking faith with the group. The question that should engage our attention now is how can the ethnic and social identity reasoning in Hebrews be understood within Akan understanding and experience?

By calling believers 'many sons and daughters' (Heb 2:10, 14), and 'brothers and sisters' to Christ (Heb 2:11), the author identifies the believers in familiar Akan kinship terms that convey a great sense of communion as one finds in life within the Akan family and clan. ${ }^{23}$ As sons and daughters, the readers have one Father who is God, and Jesus is their Brother. The introduction of 'holy brothers who share in a heavenly calling' (Heb 3:1) adds something new for the Akan. The world of the Akan does not include heaven as a place of abode that one can belong to. The place of the ancestors is Asamando, a very distant place for ghosts and yet the Akan believes that the ancestors who live there have daily experiences with the living. The important point of contact here is the sharing in a life with members living in a spiritual realm. This spiritual realm now expands to include heaven from which Akan believers now receive their calling. The note of holiness associated with 'holy brothers' may convey a sense of ritual purity performed for harmonious relationship with the spirit beings and for the peace and prosperity of the Akan community. However, the Christian perspective on holiness here is related to the sacrifice of Christ by which believers are set apart for God. Neither the concept of sacrifice for cleansing nor the use of human victim is foreign to the Akan. In Akan society, sacrifices performed with human victims in high and powerful positions are believed to yield tremendous results. The voluntary sacrifice of Akan Chiefs like Agya Ahor of the Abura-Mfante people, that some people are identified entirely in terms of their kin rolaty to the extent when their name are identified entirely in terms of their kin relationship, or even identity of the persons mamedioned their kin relationship is the way to clarify the by the names of their children, usually by the name of the most popular child so that some parents are hardly known by their real names. It is not uncommon fo parents to be called by expressions like Kwame Maame [Kwame's Mother] Akosua Papa [Akosua's Father]. Within the extended family, members are referred to in kinship terms like Me Nakuma [My youner Mother], Me Siwaa [My ferred to in kinship terms like Me Nakuma [My younger Mother], Me Siwaa [My female Father] or Me Papa Panin [My elder Father]. In the vocative, these relations are addressed in such expressions without their names. It is only when they are use in the third person that such expressions are clarified by adding the person's nam in a situation where there are many older brothers of one's father. Where the nee arises for one's identity to be clarified, depending on what one perceives to be the easiest form of identification for the one to whom one's identity is being described, the clan, the house owner or some other immediate family relation is used. For instance, one may say Asona ni Manu [Manu of the Asona Clan] or Manu a owo Opanin Kwakye fie [Manu of the house of Kwakye]. Other kinship expressions used include Agya Kwakye ba Manu [Father Kwakye's son Manu] or Ayirebi wofase Manu [Ayirebi's nephew Manu]. Akans do not have nieces and cousins. All relations within the external family are expressed in terms of father or mother and brother or sister relationships. The brothers of one's father are either the elder fathers or younger fathers [Agya panin or Agya Kuma]. The usual way to express this avoids the qualification of elder or younger; they are simply referred to as M'agya [My father]. To add the qualifying elder or younger gives too much to as M'agya [My father]. To add the qualifying elder or younger gives too much detail, which one is usually not comfortable with. All the sisters of one's father are similarly one's female fathers (Siwaa). In the same vein, the sisters of one's mother are allone's mothers. It is common in this partcular case to hear Me Napanin or Me Nakuma [My elder mother or my younger mother]. It is only the brothers of one's sister who are referred to as uncles (Wofa) and they are those whose property one inherits as a nephew (Wofase). and Tweneboah-Kodua (paramount chief) of Kumawu in Asante, may be recalled as examples (see Ekem 2005:62; Tieku 2016:141-143). Though Hebrews describes believers in familiar ethnic terms of brothers and sisters and sons and daughters, their relationship with God gives them a dimension that transcends the earthly just as their calling is heavenly, holding significance for their social identity.

Hebrews makes both Jesus and the believers superior to the angels who are presented as servants of believers (Heb 1:14). ${ }^{24}$ Moreover, by this, believers have a mediator far better than those of the Jewish religion - the angels. To make sense of the effect the author seeks to achieve, the angels must be placed next to God and before the ancestors. Once this is done, it makes both Jesus and the believers superior to the angels who are presented as servants of believers and to whom Jesus is superior (Heb 1:14). ${ }^{25}$ That is to say, the spokesperson and messenger of God to the believers, Jesus, is greater than that of the Jews and, by implication, all other mediators associated with other religions. The implication for the Akan is that one who is greater than their traditional priest (Okomfo) is the one through whom God now speaks to us. This is because the Okomfo's role in mediation is only between the living and the gods who themselves occupy a lower level in the hierarchy of the spirits than where the angels (to whom Jesus is superior) are now placed. The better evaluation of the Christian group in this light is obvious.

The ethnic description of the audience provides one frame in which to appreciate what God does for the audience. Throughout Hebrews, everything Jesus did in his humiliation and exaltation was done for the benefit of the children of God - Jesus' brothers and sisters. He came to destroy the one who has the power of death, that is, the devil, and to deliver all those who through fear of death were subject to lifelong slavery (Heb 2:14-15). This deliverance, on the surface, should make a strong appeal to the Akan who sees deliverance from death as salvation. Those who consult deities for protection do so for protection against death (premature death usually resulting from an enemy's action), among other things.

However, Hebrews is talking about something more than deliverance from death as in the prevention of an impending death. Hebrews speaks here of deliverance from death as in overcoming the fear of death so that one can go through

24. Even before believers' identification as children of God by the designation of the angels as their servants, the believers' special place with God is already hinted. Those who serve are traditionally known as nkoa or mfenaa [slaves] or asomfo [servants] in the Akan society, and they serve the significant people of the [servants] in the Akan society, and they serve the significant people of the
household. This puts believers among the significant people of God's household as household. This puts believers among the significant people of God's household as
they are those who are served. It is not just their service that is in focus here, but they are those who are served. It is not just their service that is in focus here, but
more importantly, the calibre of those who serve believers - angels, special spiritual beings who serve the Divine One. If there are reasons to see the believers as special, the enjoyment of angelic servitude is certainly one of them, and the author of Hebrews finds it necessary to establish this right from the beginning for a people who have lost the needed positive social identity. Against the Jewish community, from which some of the believers had come, the believers in Christ should appreciate the better place they have in Christ as the mediators of the Jewish law are now their servants.

25.Opoku (1977:9-10) places the ancestors next to God; the ancestors are followed by supernatural entities like the gods with special powers from God to offer assistance in specific areas of their specialty to people. Then follows the totemic animals and plants, before agents of witchcraft, magic and sorcery. Then finally animals and plants, before agents of witchcraft, magic and sorcery. Then finally
charms, amulets and talismans called suman used for protective as well as offensive purposes. 
death standing by what is right when need be. In their history, Akans know of the courage to face death. Great Akan chiefs who offered themselves for the sake of their communities did it having overcome the fear that should have made them decide otherwise. Properly understood, the author's call should make the Akan believer take inspiration from the liberation that Jesus gives from the fear of death and like their great ancestors - Agya Ahor and Tweneboah Koduah - be willing to go through death on account of their faithfulness to Christ and, for that matter, the Christian community.

Just as Akans believe that death introduces them to a new phase of life with the ancestors, Hebrews, sharing in the common faith of 1st-century Christianity, believes that death is not the end of life. Indeed, Jesus, the Brother of the many sons and daughters of God, went through death only to be exalted to sit at the place of power at the right hand of God. Now, it is this Jesus who brings many sons to glory (Heb 2:10). Akan believers can identify with this glory into which Jesus brings them. In the first place, if death is about joining the members of the community who have gone ahead as ancestors, then death should mean a reunion with their honoured Brother, Jesus, who has done so much for them. Second, by becoming his brothers and sisters, Jesus' honour has become their honour even now. The truth is that, as Hebrews spoke about Christ bringing many sons and daughters to glory, his intention was not for the audience to only imagine this glory as something stored up for them after death. His primary purpose was the positive evaluation of the social identity the believers should derive from such thought by which their loyalty to Christ and his group could be strengthened here and now. The description of Jesus' own glory is meant to indicate the ascribed honour of the Christian group. The fact that ascribed honour is key to social identity is relevant here.

With significance for the readers' ascribed honour is the concept of Son of God as applied to Jesus. Though not entirely new to the Akan, the concept Son of God can only be fully appreciated as it applies to Jesus when seen against the accompanying attributes that define him as God in Hebrews $1: 1-4 .{ }^{26}$ It is only in this sense that Jesus's sonship as distinct from the sonship (children) of all human beings to God (as held by Akans) can be understood. This implies that Jesus as Son of God is unique. The kingdom of Christ and the subjection of his enemies under his foot recalls powerful Akan kings and kingdoms that subdued their enemies. As members of Christ's kingdom, Akans should appreciate the need to fight on the side of their King while upholding the hope that their oppressors, belonging to the kingdom of their King's enemies, would be subdued, humiliated and destroyed by their King in the end (Heb 1:13).

Hebrews indicates that Jesus was anointed with the oil of gladness because he emerged victorious in the contest of mediating God's people to God as seen in his achievement of

26.Jesus not only shares the very nature of God but is also the agent of creation who successfully achieves the purification of sins as a result of which he is exalted to sit at the right hand of God (Heb 1:2-4). purification of sins, his exaltation and his loving righteousness and hating evil. ${ }^{27}$ Because of this, God now speaks through him as a Son instead of the prophets (Heb 1:2-3, 9). Yeagu no hyire [powder has been poured on him] is perhaps the Akan version of anointed with the oil of gladness. Victory in a contest comes with praises and celebrations in the Akan society. White powder (hyire) is poured on the victor in great quantity so as to make him (or her) appear white. ${ }^{28}$ In the community where the victor lives, his lot and that of his family are honour and pride. The praise of the victor becomes the subject of discussion of the community, especially among women. In cases where the victory is of benefit to the entire community, such as victory in war, songs are composed in honour of the hero and sung while women are out playing. In this light, the positive evaluation of Jesus as one who emerges victorious in the contest of mediation of his people to God and, for that matter, of the Christian group becomes obvious. The one occupying such a unique and high position as the victorious mediator with honour from God cannot be obeyed or ignored without the corresponding high level of reward or punishment as the argument in Hebrews shows.

Consistent with the idea that whatever Jesus did was for the benefit of his brothers and sisters, Jesus is presented as suffering when he was tempted so that he is able to help those who are being tempted (Heb 2:17). Key to Jesus' temptation was the option to avoid death on the cross; hence, his suffering includes his endurance of death on the cross. Against this understanding, his suffering as he was tempted should remind the Akan believer not only of the death some of their past chiefs went through for the good of their communities but also the mental agony of contemplating the fact that they had to go through death together with all that they would lose in terms of their possessions and family. Hebrews says Jesus is able to help believers who are facing even worse situations than that of these chiefs, worse because added to the trauma of possible impending death and separation from family is the constant ridicule, shame and all forms of abuse endured from members of the society. It is in this terrible situation that the Son comes to their aid..$^{29}$ and the sense of mediating God's message, the prophets, the angels and later, Moses emerges vitical priests, and Christ, are participants in a competition in which Chris

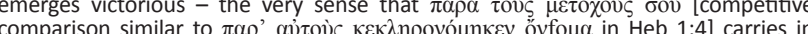

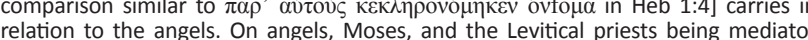
figures in the Jewish tradition, see DeSilva (2012:126). This sense of Christ emergin victorious among the prophets, angels, Moses and the Levitical priests is heavily victorious among the prophets, angels, Moses and the Levitical priests is heavily present in Hebrews (Heb 1:1, 2, 4; 2:5, 9; 3:3, 5; 10:28, 29). A number of verses become relevant here, indicating the idea of the Son emerging victorious in the spirit of the competitive comparison of Hebrews: (1) The phrase $\kappa \alpha \theta \alpha \rho \iota \sigma \mu \delta \nu \tau \tilde{\omega} \nu \alpha \mu \alpha \rho \tau \imath \tilde{\omega}$

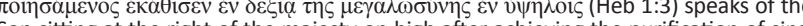
Son sitting at the right of the majesty on high after achieving the purification of sins. This carries a sense of emerging from a previous status to occupy a higher one at the right of the majesty (in the exulted place) following this achievement of purification of

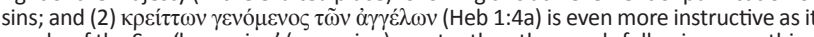
speaks of the Son 'becoming' (emerging) greater than the angels following everything

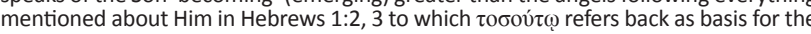
Son becoming greater than the angels.Other examples can be found in Hebrews 1:9, $5: 5,6: 20,7: 16$ and $7: 22$.

28.In Akan, it is said yeagu no hyire (i.e. he or she has had white powder poured on him or her as a sign of victory).

29.Furthermore, the believers share in Christ (Heb 3:14) and enter God's rest because they believe in Christ (Heb 4:3). The sharing in Christ possesses no difficulty to the Akan because it brings to mind Akan concepts of sharing in one's possessions as in inheritance as well as the privileges of ascribed honour. Entering God's rest can only be understood by placing it in the Jewish concept of God's promised rest now applied to the believers in Christ. The same should be said about believers being called to draw near with confidence to receive mercy and grace from the throne of 
Very important for the argument of the author is his indication that his audience are enlightened and have tasted the heavenly gift, shared in the Holy Spirit, and tasted the goodness of the word of God and the powers of the age to come (Heb 6:4-5). The Akan understanding of an enlightened person (nimdefo) carries the notion of one who has gone through the right training (ntetee) so that one knows exactly how to behave in a given situation. Akan understanding of nimdefo is akin to Hebrew's use of the 'enlightened' and perfectly serves Hebrew's employment of the expression as basis for demanding the appropriate conduct from his audience in their current circumstances. Because they have shared in the Holy Spirit, tasted the goodness of the word of God and the powers of the age to come (Heb 6:4-5), they are required as enlightened children of God to return the favour to God their Father. The Akan saying that most expresses this obligation of children to parents is wo awofo hwe wo ma wosi fifi a, wo nso whe won ma won se ntutu - literally meaning 'after your parents have nurtured you to grow your teeth, you should also take care of them while they lose their teeth' (Dolphyne, pers. comm., 04 July 2016). The saying implies that children should not abandon their parents in trying moments. It would therefore not only be a shame but also evil in Akan thought if the believers should abandon their Father (God) who through their Brother (Jesus) has granted them all the benefits mentioned pointed out in Hebrews. ${ }^{30} \mathrm{It}$ is the light of the Father's great beneficence and believers' obligation to return favour that all the benefits in Hebrews should be considered. Their hope in Christ gives them a better possession, an abiding one (Heb 10:34). Even the suffering they are going through is God's discipline that is meant for their good (Heb 12:7-11). Theirs is the heavenly city (Heb 12:22) and the kingdom that cannot be shaken (Heb 12:28). All these benefits and more are available to the members because their Father through Jesus, their Brother, made them possible. ${ }^{31}$ The Akan adult child who fails to take care of his or her parents in their old age is never forgiven the evil of his or her action. Not only do parents complain and

\section{(footnote 29 Continues...) \\ grace because they have a high priest who is able to sympathise with their weakness (Heb 4:15-16). No concepts of throne of grace and receiving grace and mercy, as in this context, exist in Akan thought. The closest one can come to is receiving pardon from a chief for a misdeed and especially in the event that one supposed to be executed is allowed to 'buy his or her head'. Hebrew's use of receiving grace and mercy to help in times of need has in view the help needed to continue to remain faithful while enduring hostility and persecution.}

30.The benefits the believers enjoy from their Father are expressed elaborately in a variety of expressions in Hebrews (sometimes with many such expressions referring to the same benefit) to underscore the evil of believers inappropriate response to God's manifold goodness. It is noted, for instance, that sharing in the about the same benefit (Heb 6:4-5). Buchanan $(1972: 219,285)$ notes the author's habitual use of different expressions for the same thing.

31.With his emphasis on what God has done for his people in religious terms, the author further indicates that the consciences of the audience are purified through the blood of Christ who through the eternal Spirit offered Himself without blemish to God (Heb 9:24). He enters the holy places not made with hands to appear before God on behalf of his people (Heb 9:24). He has perfected them as those who are being sanctified by a single offering (Heb 10:14). Their hearts are sprinkled clean from an evil conscience and their bodies washed with pure water (Heb 10:22). They have also been sanctified through the offering of the body of Jesus Christ once for all (Heb 10:10). The concept of a once for all sacrifice is Christian and unknown to the Akan in so far as it has to do with the purification that deals with unknown to the Akan in so far as it has to do with the purification that deals with sin and defilement. Yearly and other occasional rituals need to be performed to achieve ritual cleansing from sin and defilement in Akan thought. As noted earlier, the concept of human victim for the performance of highly potent sacrifices is not foreignto the Akan. The idea of cleansing one's conscience from guilt and sin is also present in the Odwira festival, which is done for the purification of the people. It intent is, however, not primarily for approach to a deity as it is for harmonious living in the community that involves both spiritual and the human members. sigh over the thought of such ingratitude but also members of the community never cease to decry such a person. It is therefore not difficult for the Akan believer to appreciate Hebrews' argument that God has done so much for his children to make their abandonment of him in their suffering an unforgivable offense.

If the believers should endure suffering, it is because it is God's way of training them as legitimate children (Heb 12:8). In the Akan society, ntetee [training] is required of all who are expected to know their obligations and fulfil them as responsible members of the family. Candidates for chieftaincy go through rigorous training because of the importance of the charge they will assume. If the Akan believer is to inherit all the immense privileges and benefits so described in Hebrews, then the best training must be obtained, and as Hebrews indicates, such training is not meant to be easy, hence their experience of suffering God's $\pi \alpha 1 \delta \varepsilon i ́ \alpha$ (training; Heb 12:5-11).

Hebrews' line of argument based on the conviction that believers must behave in a manner characteristic of the people of God can be understood in light of the Akan belief and expectation that people behave in a manner consistent with that of the ethnic group to which they belong. The usual phrases such as Akanni nkasa saa [an Akan does not speak like this] and Akanni nnye saa [an Akan does not do that] express this belief and expectation. As noted of the character of the Akan person, the sunsum inherited from the father determines the character traits of the child. The nton, also of the father and to which the child belongs, has strong indications for one's character and determines, among others, one's taboos and prohibitions. The fact that steps are taken to inculcate the expected character traits in the child also provides further basis for expecting children to exhibit these traits as the writer of Hebrews does of his audience. The author intends the qualities of Jesus portrayed in Hebrews to be seen as typical of members of the family of God as those qualities are reflections of God their Father. Throughout Hebrews, these qualities of Jesus define what must be one's right attitude to suffering as faithful children of God. Jesus suffered death which he tasted for everyone, and he was crowned with glory and honour as a result (Heb 2:9). He is faithful over God's house as a Son (Heb 3:6). He was tempted but no sin was found in him (Heb 4:15). Jesus succeeded in his faithfulness because he took to a number of ways: In the days of his flesh, he offered up prayers and supplications with loud cries and tears to him who was able to save him from death, and he was heard because of his reverence (Heb 5:7). He learnt obedience through what he suffered, and being made perfect, he became the source of salvation to all who obey him (Heb 5:8). For the joy set before him, Jesus endured the cross scorning its shame and is now seated at the right hand of the throne of God (Heb 12:2). By all these, he managed to endure such hostility against him from sinners so that as the believers consider him, they too will not grow weary or fainthearted (Heb 12:3). The implication for the believers is clear: They too, like Jesus, must follow these ways of Jesus their Brother who has received God's approval and be what they are supposed to be too as children of God. In this light, 
the description of Jesus as pioneer and perfecter of our faith has relevance for the audience to be like Jesus. ${ }^{32}$

The importance of the religious language used to describe the role of Jesus is significant. Jesus is the 'high priest of our confession' who is able to sympathise with us. ${ }^{33} \mathrm{He}$ is also the 'great high priest who has passed through the heavens' where he performs his sacrifice (Heb 3:1; 4:15; 9:11) and is 'the source of eternal life to those who obey Him' (Heb 5:9). ${ }^{34}$ While Akans and Hebrews share in the belief of a life that continues even after death, the quality of life as good life is different in the two. Eternal life as good life for the Akan implies life without suffering in prosperity, but for Hebrews, it involves also the power to endure suffering and hostility in this present life. ${ }^{35}$ The Akan adage akokoba a oben oni no na odi abebe sre [the chick that stays with the hen gets the thigh of the grasshopper] speaks to need for allegiance to one's parent or leader in order to get the best from him or her. Conversely, siantie ne onwam atikopo [the block at the back of the head of onwam [a wild bird] is due to its disobedience] points to the evil consequences of disobedience. These two adages reflect the social requirement that parents in particular and elders in general should be obeyed. At the same time, they speak of the blessing of obedience and the evil consequences for disobedience. This Akan social requirement of obedience should give meaning to Hebrew's insistence that it is to those

32.The description of Jesus as the founder and perfecter of the faith of believers makes Jesus the model in His religious life and attitudes for Akan believers in how they should pursue their faith journey in their present situation (Heb 12:2). psatwafo is the vanguard who leads and clears the path to be followed. As the destination becomes the final designation of his followers.

33.The sympathising high priest hardly has any similar Akan concept and is to be appreciated both from the perspective of Jewish cultic practices, as well as Christian description of Jesus' ministry in which he is both the high priest as well as the victim of the sacrifice. Akan priests perform rituals for the benefit of adherents including rituals for cleansing. These rituals are done for a fee. There are no known qualifications for traditional priests that prescribe the ability to sympathise with one's brothers and sisters. A sense of responsibility can surely be expected of Akan traditional priests, while absence of their sympathy for adherents cannot be claimed even if such sympathy may not be granted to all. The identification of Jesus as the high priest takes ethnic relevance not only in his designation as their own as the high priest takes ethnic relevance not only in his designation as their own Brother but also in the fact that religion is imbedded in Akan ethnic groups such as the household, family or the Bonsam Shrine. The holding the wellbeing of his family at heart just as Akan family deities have family holding the wellbeing of his family at heart just as Akan family de
members who know how to solicit assistance from those deities.

34.Peculiar to Christian belief is the idea that Jesus performed his priestly ritual for cleansing in a heavenly place not made with hands (Heb 9:11). For the Akan, the sphere of the spiritual is not the place for the performance of ritual. Rituals are performed by the living members of the community to spirit beings who respond with their benevolence. Hebrews' identification of the heavenly sphere as the place of the sacrifice of Christ is meant to underscore the superiority of His sacrifice to all that are performed in the world of human existence. The Akan believer can hardly miss this import. By its superiority to all sacrifices made in the sphere of hardly miss this import. By its superiority to all sacrifices made in the sphere of human existence, the greatness of God's beneficence towards his people underscored. Within Akr nature of God's action for his people - the very point the author seeks to make.

35.For the Akan, the idea of eternal life could be understood in terms of the cycle of life which continues even in death with the ancestors. Such a life involves the wellbeing of the family in this present life shared by both the living and the living dead. However, Hebrews' use of the term expresses a quality of life with God which liberates one from all forces to enable one to live in all conditions, assured of better life with God after death. Hebrews' concept of eternal life does not necessarily imply a life without suffering and hostility as the Akan concept holds. Jesus being the source of eternal life, for the Akan, may readily find expression in the Akan thought in which the ultimate goal of all consultation with a deity is the peace and prosperity of the family in this present life. Eternal life should be understood by the Akan in terms of the unbroken life which continues with the andestors byen Akan in terms of the unbroken life which continues with the ancestors even in death. This is where the difference lies: for the Akan, eternal life must imply a good life which should be free of all ills in this present life, but for Hebrews, the good lif (eternal life) can be experienced in the here and now even in the midst of adversity. For both the worldvew of the Akan and Hebrews, life continues even after death. The difference lies in where one spends the life, whereas it is with the ancestors for the Akan and for the Hebrews, it is with God. who obey Jesus that he is the source of salvation (Heb 5:9), emphasising the need for the readers to continue in obedience and faithfulness to the Lord.

Hebrews' use of name and language to describe the group of his listeners favourably and outgroups unfavourably has similar use in the Akan society. It has already been observed that Akans see themselves as the most civilised and foremost among their neighbours. Even among Akan tribes, such use of name and language exists. ${ }^{36}$ The import of such use of names and language by Hebrews is not difficult for the Akan to appreciate. Hebrews' description of his audience as God's house (Heb 3:6) and as people who have come to share in Christ (Heb 3:14) is set against the unbelieving Jews represented by the wilderness generation, described as rebellious people who provoked God and sinned, resulting in their bodies falling in the wilderness. ${ }^{37}$ For the Akan Christian, the author's intent should be clear; he wants the believer to appreciate how better placed they are so that they would persevere in their current difficult situation on account of how much God has accomplished for them which must not be made to be in vain.

Recall of shared historical memory as a feature of ethnicity is done for a variety of purposes. This practice in the Akan society offers a window through which to appreciate Hebrews' use of recall of shared historical memory. The Chief of the Akan town of Tafo in Kumasi, Nana Agyen Frimpong, recalled the participation of the people of Tafo in all the Asante wars to underscore the fact that Tafo people are not cowards. This was during recent disturbances between the Muslims of Tafo Zongo and the citizens of Tafo. The Chief did this to underscore the fact that Tafo people are not cowards and, therefore, the fact that they did not respond with violence to the Muslims was just for the sake of peace (Tafohene, Nana Agyen Frimpong, Peace FM, 6 pm news, 03 July 2016). If the chief had intended to stir courage in his subjects with this shared historical memory recalled for retaliation, the effect would have been obvious. Nana Yaa Asantewaa effectively made use of the recall of shared historical memory and got the Asante kings to go to war with the British army. ${ }^{38}$ The author of Hebrews often recalls

36.It is often said that Kwahu people are tight-fisted (pepee) and boastful (huhuu as as well as skilful in doing business. Akyem people are said to be litigants (mansotwifo). Kwabane Nketia (emeritus professor of music, University of Ghana, pers. comm. 05 July 2016) observes that Akyem people are not very assertive (anioden) but are confident. Akuapem people are noted for their extreme show of respect to the extent that they beg before insulting someone. Asante people are said to have cent sense of superiority and are boastful. The Fantes are described as fancying Western style of life in both their speech and taste for food. They mix the Fante Twi with very good at comedy as well.

37.The result was that God swore they would not enter His rest (Heb 3:16-19). In contrast to the unbelieving Jews, the believers, of whom the author feels better things that belong to salvation (Heb 6:7-9) can draw near to the throne of grace (Heb 4:16). The believers are enlightened people of God (Heb 6:4-5) as opposed to those outside the group considered to be in the dark (cf. Heb 10:32). Moreover, they have demonstrated good works for which God will reward them (Heb 6:10-11). Unlike the wilderness generation, they will receive what has been promised by doing God's will in their endurance (Heb 10:35) because they are not of those who shrink back and are destroyed, but those who have faith and preserve their souls (Heb 10:39). They have a common source with Christ in God as well as in Christ (Heb 2:11; 5:9; cf. 4:6; 3:18-19).

38.When Yaa Asantewaa called the chiefs of the Asante Kingdom to arise as men of Osei Tutu and Opoku Tenten, she recalled the memory of the military exploits of Nana Osei Tutu and Opoku Tenten and succeeded in getting the chiefs go to war against the British even though they had initially shown cowardice. By recalling their shared historical memory, the chiefs were not only reminded of the their shared historical memory, the chiefs were not only reminded of the
community of brave people to which they belong but also had their courage community of brave people to which they
restored and stirred for the desired response. 
shared historical memory to reinforce the group identity of his audience as people who belong to God as well as reawaken heroic deeds of past generations (and of their own) in the audience. It also helps him to stress their obligations to the group in ministry to one another. Hebrews describes the recipients as people who have demonstrated their love in the service of the saints in the past for which God will reward them (Heb 6:10). The audience stand in line with the historical experience of the heroes of faith as in a relay race because on the one hand, the heroes have run the race of faith before, and on the other their perfection depends on what God is doing now in Christ in which the readers have their current experience (Heb 11:40). The life of Esau is recalled as an example of an immoral character to be avoided because he made a hasty decision for the pleasure of the moment and lost his more valuable and enduring right to inheritance which he later sought in vain to regain. The believers under the pressure of the moment stand in a similar situation as Esau, but they should guard against any decision to go for the ease of the moment and miss the eternal reward God has for them. Jesus's own example is also recalled from their common historical memory to which it now belongs, and he becomes the sole model on whom the gaze of the audience should be constantly fixed. This makes Jesus the prototypical member of the group holding the ideal image of the group's character. In His character is embodied the ideals of the group; hence, being like him is being a true member of the group. As they look away to him, they should be able to run the race the way Jesus did, despising the shame and enduring their suffering in faithfulness to God (Heb 12:2). In this way, the author finds in the historical memory shared by the believers with the Jews a strong ethnic appeal for courageous stance for one's family as is found in the Akan society.

\section{Summary}

With the lens of Akan concept of ethnicity, the author is seen to be arguing in familiar kinship terms that express close family relationships as within the basic family unit headed by the father. The exception is the distinctive Christian and Jewish thought in the author's argument that must be understood on their own terms and which usually point to the superiority of the Christian privilege. If the believers' Brother is glorified at the right hand of God and brings many sons and daughters to glory, the Akan experience of sharing the honour of a family member as well as joining the honoured ancestors in death provides a useful lens to appreciate what Hebrews is saying. The Akan understanding of nimdefo gives meaning to the author's designation of believers as enlightened people that helps him to demand the right conduct from his readers as is expected of them. The Akan understanding of ntetee [training] as difficult but necessary for children who are potential heirs provides a good way to understand the suffering of the readers as God's straining of his legitimate children who are to inherit salvation and all the benefits of God. The role of otwafo in Akan gives insight into the role of Christ described as the author and perfecter of faith so that Christ does not only cut the path but also lead and make his final designation that of the believers too. When the author's statements about the religious achievements for the believers are considered against Akan religious pursuit for wellbeing of the family, the ethnic significance of the author's statement is made clear. The Akan proverb that spells out the responsibility of adult children towards their parents particularly speaks to the author's appeal for the audience not to abandon their Father (God) after all he has done for them and stresses the evil of doing otherwise. Names and language used by Akans to describe themselves positively and others negatively offer insight into Hebrews' similar use of names and language. Similar to Akan use of common historical memory to stir up virtues and right conduct in people is Hebrews' use of the same, offering the Akan believer a familiar perspective on the author's use of historical memory.

\section{Acknowledgements Competing interests}

The authors declare that they have no financial or personal relationships which may have inappropriately influenced them in writing this article.

\section{Authors' contributions}

This article represents a reworked version of aspects from the $\mathrm{PhD}$ dissertation of S.K., titled 'Social identity in Hebrews and the Akan community of Ghana', in the Department of New Testament Studies, University of Pretoria, with E.v.E. as supervisor.

\section{References}

Agyekum, K., 2006, 'The sociolinguistic of Akan personal names', Nordic Journal of African Studies 15(2), 206-236.

Appiah, K.A., 1992, In my father's house: Africa in the philosophy of culture, Oxford University Press, New York.

Awinongya, M.A., 2013, The understanding of family in Ghana as a challenge for a contextual ecclesiology, viewed 03 June 2016, from https://books.google.com.gh/boo ks?id=0iCOB4|Sa50C\&pg=PR3\&dq=communal+living+akans+in+ghana\&source=gbs

Barth, F., 1969, 'Introduction', in F. Barth (ed.), Ethnic groups and boundaries: The social organization of culture difference, pp. 9-38, Little, Brown and Company, Boston, MA.

Boahen, A.A., 1966, 'Origins of the Akan', Ghana Notes and Queries 9, 3-10, in F.A. Dolphyne, n.d., The language of the Akan people, viewed 30 May 2016, from http://anyiliteracy.org/publications/dolphine_Florence_1986_History_of_the_ Akan_People.pdf

Buah, F.K., 1998, A history of Ghana, rev. edn., Macmillan, Oxford.

Buchanan, G.W., 1972, To the Hebrews: Translation, comment and conclusions, Doubleday \& Company Inc., Garden City, New York.

Buell, D.K., 2005, Why this new race: Ethnic reasoning in early Christianity, iBook reader format, Columbia University Press, New York.

Busia, K.A., 1954, 'The Ashanti', in D. Forde (ed.), African worlds: Studies in the cosmological ideas and social values of African peoples, pp. 190-209, Oxford University Press, London.

Cockerill, G.L., 2012, The new international commentary on the New Testament: The epistle to the Hebrews, William B. Eerdmans Publishing Company, Grand Rapids, MI.

Craddock, F.B., 1998, 'The letter to the Hebrews', in L.E. Keck (ed.), The new interpreter's Bible in twelve volumes, vol. 12, pp. 1-173, Abingdon Press, Nashville, TN.

Cromhout, M., 2014, 'Israelite ethnic identity responding to the Roman imperium in revelation', in J.B. Tucker \& C.A. Baker (eds.), T\&T Clark handbook to social identity in the New Testament, pp. 59-78, Bloomsbury T\&T Clark, London.

Danquah, J.B., 1968, The Akan doctrine of God: A fragment of Gold Coast ethics and religion, Frank Cass \& Co. Ltd., London.

Davidson, B., Buah, F.K. \& Ajayi, J.F.A., 1965, The growth of African civilisation: A history of West Africa 1000-1800, Longman, London.

DeSilva, D.A., 2012, The letter to the Hebrews in social-scientific perspective, Cascade Books, Eugene, OR.

Dolphyne, F.A., n.d., The language of the Akan people, viewed 30 May 2016, from http://anyiliteracy.org/publications/dolphine_Florence_1986_History_of_the_ Akan_People.pdf 
Duling, D.C., 2010, 'Ethnicity and Paul's letter to the Romans', in D. Neufeld \& R.E. DeMaris (eds.), Understanding the social world of the New Testament, pp. 68-89, Routledge, London.

Ekem, J.D.K., 2005, New Testament concepts of atonement in an African pluralistic setting, SonLife Press, Accra.

Eshun, E.K., 2011, Religion and nature in Akan culture: A case study of Okyeman environmental foundation, viewed 29 May 2016, from https://qspace.library. queensu.ca/bitstream

Esler, P.F., 1998, New Testament readings: Galatians, Routledge, New York.

Esler, P.F., 2014, 'An outline of social identity theory', in J. B. Tucker \& C.A. Baker (eds.) T\&T Clark handbook to social identity in the New Testament, pp. 13-39, Bloomsbury T\&T Clark, London.

Fortes, M., 1975, 'Kinship and marriage among the Ashanti', in A.R. Radcliffe-Brown \& D. Forde (eds.), African systems of kinship and marriage, pp. 252-284, Oxford University Press, London.

Ghana Statistical Service, 2013, National analytical report: 2010 population \& housing census, Ghana Statistical Service, Accra.

Gyekye, K., 1996, African cultural values: An introduction, Sankofa Publishing Company, Accra.

Jokiranta, J., 2013, Social identity and sectarianism in the Qumran movement, Brill, Leiden, the Netherlands.

Kissi, S., 2017, 'Social identity in Hebrews and the Akan community of Ghana', PhD thesis, Department of New Testament Studies, University of Pretoria.

Kuecker, A., 2014, 'Ethnicity and social identity', in J.B. Tucker \& C.A. Baker (eds.), T\&T Clark handbook to social identity in the New Testament, pp. 59-78, Bloomsbury T\&T Clark, London.

Malina, B.J., 1996, 'Understanding New Testament persons', in R.L. Rohrbaugh (ed.), The social sciences and New Testament interpretation, pp. 42-61, Hendrickson Publishers, Peabody, MA.
Meyerowitz, E.L.R., 1958, The Akan of Ghana: Their ancient beliefs, Faber and Faber Ltd., London.

Nkansa-Kyeremanteng, K., 2010, The Akans of Ghana: Their customs, history and institutions, 2nd rev. edn., Sebewie De Ventures, Santasi, Kumasi.

Opoku, K.A., 1977, West African traditional religion, FEP International Private Limited, Accra.

Rattray, R.S., 1929, Ashanti law and constitution, The Clarendon Press, Oxford.

Salm, J.S. \& Falola, T., 2002, Culture and customs of Ghana, viewed 03 July 2015, from https://books.google.com.gh/books?id=Up EcXthzCcC\&pg=PR3\&dq=ethnic+gro ups+in+ghana\&source $=$ gbs_selected

Sarpong, P.K., 2002, Peoples differ: An approach to enculturation in evangelisation, Sub-Saharan Publishers, Legon, Accra.

Shumway, R., 2011, The Fante and the transatlantic slave trade, viewed 05 March 2015, from https://books.google.com.gh/books?id=3xc5kJlt4AYC\&printsec=front cover\&source=gbs ge summary $r \&$ cad $=0 \#$

Siapkas, J., 2014, 'Ancient ethnicity and modern identity', in J. McInerney (ed.), A companion to ethnicity in the ancient Mediterranean, iBook reader format, Wiley, Chichester, West Sussex.

Tajfel, H., 1982, Social identity and intergroup relations, viewed 26 August 2015, from https://books.google.com.gh/books?id=h_YA9CYXgGOC\&printsec=frontcover\&d $\mathrm{q}=$ social+identity\&hl=en\&

Tieku, A., 2016, Tete wo bi kyere: History \& facts about Asante Kingdom and Ghana Schrodinger's Publications, Kumasi.

Turner, J.C., 1984, 'Social identification and psychological group formation', in H. Tajfe (ed.), The social dimension - European studies in social psychology, vol. 2 pp. 518-540, Cambridge University Press, London.

Van Eck, E., 2014, 'Inclusivity as the essential nature of the Gospel', in J. Kok \& J.A. Dunne (eds.), Insiders versus outsiders: Exploring the dynamic relationship between mission and ethos in the New Testament, pp. 49-83, Gorgias Press, Piscataway, NJ. (Perspectives on Philosophy and Religious Thought 14). 